\title{
XLVIII. Observations upon alicant wine, and particularly the alicant raisin wine
}

\author{
M. Pissis M. D.
}

To cite this article: M. Pissis M. D. (1806) XLVIII. Observations upon alicant wine, and particularly the alicant raisin wine , Philosophical Magazine Series 1, 25:100, 313-317, DOI: 10.1080/14786440608563454

To link to this article: http://dx.doi.org/10.1080/14786440608563454

曲 Published online: 18 May 2009.

Submit your article to this journal $\widetilde{ }$

Џ Article views: 2

Q View related articles $\asymp$ 


\section{$\left[\begin{array}{ll}313 & ]\end{array}\right.$}

XLVIII. OUservations upon Alicant Wine, and particularly the Alicant Raisin Wine. By M. Pissis, M. D.*

Alicant wine, one of the most precious cordials in pharmacy, has the agreeable colour of red wine added to the mildness of a wine made of must, and it is generally allowed that it has been prepared in this manner. It is evident that the must which produced it had been coloured before fermentation. The only raisin yet known to furnish this kind of must is called the Plant of Alicant; in our country it is known by the name of teinturier, or tachant. It is bitter, and ripens badly in the centre part of France; but the further we advance to the southward the better are the wines it produces, and the more do they resemble the wines of Spain. I have no hesitation in saying, that with the cultivation and treatment resorted to at Alicant, we may be able to imitate the Spanish wines in the south maritime districts of France.

The colouring matter of the Alicant raisin is the same as that of the red fruits and common red wines; it has the singular property of becoming red by the acids: although blue by nature, it becomes green with the alkalis, and the colour is destroyed by the strong oxygenating substances; but in the common raisin this colouring matter is not dissolved except by alcohol, when the must has fermented: while in the teinturier, and the most of the red fruits, it is diluted in their juice. Is the nature of this matter changed in these different fruits, or is it always the same? and is it not, except by means of intermediate substances, resinous or extractive, that this principle is dissolved equally well by the aqueous juices as by alcohol? Scveral experiments incline me towards the latter opinion : besides, it is more conformable to the simple and constant progress of nature; it is also that of M. Chaptal, who, in his Essay upon Wines, refers the colouring principle of red wine to the fecula.

My object is not to expatiate more upon this principle; I have already described it fully in a letter written to M. Chap-

* Annales de Chimie, tome lvii. p. 5.

Vol. 25. No. 100. Sept. 1806. X

tal, 
tal, when minister of the interior, who honoured me with a most flattering approbation of its contents. That letter contains the theory of the deletcrious effects of wines and casks, with the most efficacious method of preventing injuries, founded upon authentici experiments collected during these four years. Circumstances have occurred to hinder me from printing this work ; but I think it useful to communicate one of the facts which by chance occurred, and which appeared extremely worthy of attention, by its importance to the healing art. .

Last year I attended a patient, to whom I frequently administered Alicant wine, which I was perfectly certain was genuine, and it was twenty years old. The patient romited frequently, and violet-coloured pellicles were seen floating upon the matter vomited : these I took at first sight for the refuse of the coat of the stomach, as I had often seen the like in cases of gangrene in that organ,-with this difference, however, that in the latter case the colour is always more livid: I also remarked that the smell of the former pellicles was acid, and not putrid; they did not appear upon every occasion of romiting, and they were attended with no other symptom of gangrene.

I concluded from these observations that there must be some chemical illusion in the case. I mixed all the liquids which were administered to the patient with one another; and $I$ at length discovered that these pellicles, so alarming in their appearance, were occasioned by the mixture of Alicant wine with fat broth; and of this all the attendants were also convinced.

The moment the mixture was made the wine lost its colour entirely, and violet-coloured flakes floated on the liquor, like the scrapings of a cask. No other wine produced any such effect. Several kinds, sold for Alicant wines, were also tried without effect. Presuming that the abore phænomenon was occasioned by the peculiar nature of the plant, I requested M. Heraud, a good apothecary, and who has the teinturier among his vines, to make some experiments, which I was prevented from undertaking myself in consequence of other 2vocations. M. Heraud accordingly ex- 
pressed the must from some Alicant raisins; but this thick and muddy must produced no sensible effects upon soup. M. Heraud then set the must which remained to ferment; and he ohtained a fine red wine, very pleasant although not very mellow, and which precipitated the broth as well as the true Alicant wine which M. Heraud had in his shop. It is easy to see that the mucous and saccharine bodies which render the must of Alicant viscous, keep the precipitate suspended, as it happens with ink when strongly gummed; and that fermentation, by destroying a part of these viscous bodies, had rendered the play of the chemical affinities quite free. It is thus that we extract gelatine from quinces and other astringent fruits, without the tannin which they contain forming any precipitate with the gelatine.

The fat broth, well boiled and skimmed, contains, among other principles, gelatine; and as of all the known vegetable matters gelatine is most easily precipitaled by tannin, it follows then, of course, that the latter principle exists in Alicant wine and raisins. This tannin serves for the intermedium to the colouring principle, and keeps it dissolved in the water; also the colouring principle forms the greater part of the precipitate; not that the gelatine acts upon it, since it does not act upon the ordinary red wines, but because in this case the kind of colouring principle is united to that of the tannin, its intermedium. The yellow colour of the tannin gives the $r \in d$ wine of Alicant an orange cast. Upon precipitation the colour becomes violet, because the malic acid remains dissolved, and does not redden the colouring principle. The latter would even become much bluer if it did not retain some atoms of tartar.

When the made wine is evaporated, the alcohol carries off with it a part of the malic acid, and the residue becomes so much the more violet-coloured the less tartarous it is. But in the juices of red fruits, and of the teinturier, the malic acid, deprived of the intermedium of the alcobol and retained by the saccharine body, remains fixed, in spite of the operations they undergo, and preserves the red colour of these juices. 
We may also conclude, that to clarify the wine or the must of Alicant with animal substances, which will discolour them more or less, is attended with inconvenience. The teinturier is not the only fruit which contains tannin; several bitter fruits, without doubt, present it to the chemists also; it is in the fermented juices that they discover it by the acid of gelatine.

It is singular that tamnin does not give a bad taste to Alicant wine, considering the disagreeable taste which common wine derives from being put into a cask of new oak; but which is easily carried off, as I myself ascertained, by fining down the wine with gelatinous substances. Are there $s \in-$ veral kinds of tannin which differ in smell? or is the smell of tannin modified in its union with the colouring principle? This last conjecture appears extremely probable. Wine which has fermonted in a new oak tub derives no bad taste from it; we cannot deny that there is here plenty of tannin, which is modified, without doubt, by the fermentation, and assimilated to the tannin of the Alicant wine.

Purchasers of Alicant wine will now be in possession of a sure and casy method of ascertaining the quality of the wine sold them as Alicant; a red colour with a slight orange cast, a sweet and spirituous taste with a sharp bitterish flavour, and the property of precipitating gelatine,-all these are the characteristics of genuine Alicant wine. Without the last property in particular, no wine, however good, is genuine Alicant. Boerhaave, in his treatise on nervous diseases, complains loudly of dealers who colour their wines with sumach. Red fruits, and even the teinturier itself, are also resorted to for this purpose. Alicant wine is also made in some countries, but the operation is not performed in the Spanish manner. All these wines ought to precipitate gelatinc more or less; we must therefore have recourse to attentive tastings, and other proofs already known, in order to discover them.

The well known nature of Alicant wine enables us to ascertain in what diseases it should be resorted to. The tannin it contains places it at the head of the astringent 
wines of the antients, so precious in atonic and colliquative fluxes; it is of course necessary to have it of the very best quality. It must not be resorted to in constipations.

Patients of the lower class often request that their wine may be mixed with their soups. It can be attended with no inconvenience to grant them this indulgence; but when Alicant wine is made use of, they ought to be told that a most disgusting beverage results from such a mixture. It is even prudent not to allow fat soups to be taken at the same time with Alicant wine, when treating such as have delicate stomachs. To conclude: the decomposition of Alicant wine in the stomach can have no more bad consequence than all the other wines have upon meeting with the digestive juices; and particularly with the bile, which contains pure soda. Every thing which cannot form part of the chyle necessarily goes into the alvine secretions.

XLIX. Chemical Olservations upon Spathic Iron. By M. Collet Descostils, Engineer of Mines.

[Continued from p. 251.]

$T_{\mathrm{HE}}$ results which $\mathrm{I}$ have related, in my opinion, prove that the ores of spathic iron vary in their composition, and consequently explain the difference of those obtained by Bergman, Bucholz, and Drappier. Perhaps from new analyses still more variations may be made known.

It would no doubt be very advantageous to be able to distinguish each varicty by its exterior characters, because their different compositions ought to have a different treatment in order to obtain the iron from them. The form of the laminæ, and their texture, serves to distinguish spathic iron into two species in the iron-works of Old Dauphiny. The one which is named maillat is composed of large flat laminæ; the other, the crystallization of which is confused, and the lamina rounded, is called rives. The first fuses with difficulty; the second, or that with small grains, is, on the contrary, remarkable for its fusibility and for the quality of its pigs, which yield steel easily. The latter is generally white, 